\title{
FAKTOR RISIKO YANG BERHUBUNGAN DENGAN KEJADIAN MYOPIA PADA ANAK USIA SEKOLAH
}

\author{
Musiana*, Nurhayati*, Sunarsih* \\ "Jurusan Keperawatan Poltekkes Tanjungkarang \\ Email: musiana74@gmail.com
}

\begin{abstract}
Hingga saat ini diperkirakan sebanyak 1,6 miliar penderita miopia dan kemungkinan meningkat hingga 2,5 miliar pada tahun 2020. Miopia banyak ditemukan pada anak-anak sekolah. Data WHO menunjukkan 10\% dari 66 juta anak sekolah menderita gangguan refraksi yaitu myopia. Hasil presurvey pada siswa SMPN 2 Tanjungkarang didapatkan data lebih dari 20 siswa mengalami myopia. Tujuan penelitian ini adalah diketahuinya faktor risiko yang berhubungan dengan miopia pada anak sekolah. Jenis penelitian kuantitatif menggunakan pendekatan case control. Sampel diambil dengan teknik purposive, sebanyak 44 responden terdiri dari 22 siswa miopia dan 22 siswa tidak myopia. Hasil penelitian didapat ada hubungan antara faktor risiko keturunan, faktor risiko aktifitas jarak dekat dan faktor risiko aktifitas di luar ruangan dengan kejadian miopia pada anak sekolah dengan $\mathrm{p}$ value $=0,018 ; 0,001$ dan 0,048 . Tidak ada hubungan antara faktor risiko jenis kelamin dengan kejadian miopia pada anak sekolah dengan $\mathrm{p}$ value $=1,000$. Hasil penelitian diperoleh nilai odd rasio (OR) untuk masing-masing faktor risiko yaitu faktor jenis kelamin $(1,000)$, faktor keturunan $(\mathrm{OR}=11,560)$, faktor aktifitas jarak dekat $(\mathrm{OR}=11,560)$ dan faktor aktifitas luar ruangan $(\mathrm{OR}=0,773)$. Saran, responden agar untuk faktor risiko yang dapat diubah yaitu membatasi aktifitas jarak dekat, tidak lebih dari 5 jam dalam sehari seperti membaca jarak dekat, bermain smartphone dan menonton televisi, dan lebih meningkatkan jumlah jam untuk aktifitas di luar ruangan seperti kegiatan olah raga.
\end{abstract}

Kata Kunci: Miopia, faktor risiko

\section{LATAR BELAKANG}

Miopia atau yang lebih sering disebut dengan istilah rabun jauh merupakan kondisi gangguan penglihatan berupa gangguan refraksi, dimana saat melihat objek dekat individu dapat melihat dengan jelas, tetapi saat melihat objek yang jauh tampak kabur. Miopia terjadi apabila bola mata terlalu panjang atau kornea terlalu cembung sehingga cahaya yang masuk ke mata jatuhnya tidak tepat di retina sehingga objek yang jauh terlihat kabur (Yu et. al, 2011). Miopia berkembang bersamaan dengan perkembangan tubuh yaitu pada masa pubertas dan biasanya berhenti berkembang di usia 25 tahun (Youngson, 1995). Puncak miopia pada usia remaja dan paling banyak terjadi pada anak perempuan dari pada lakilaki dengan perbandingan 1,4:1.

Prevalensi miopia semakin meningkat, dari tahun ke tahun, sebanyak 1,6 miliar penderita miopia dan diprediksi akan meningkat jumlahnya hingga 2,5 miliar pada tahun 2020. Prevalensi miopia pada orang dewasa di Amerika sekitar 20-50\%, dan di negara Asia 85-90\%. Prevalensi miopia pada anak-anak di negara barat kurang dari 5\%, sedangkan anak-anak di Asia lebih tinggi prevalensinya sekitar 29\% (Yu et al., 2011). Menurut WHO sebanyak $43 \%$ kelainan refraksi dapat menyebabkan kebutaan (WHO, 2011) apabila tidak terkoreksi, untuk itu melalui peringatan World Sight Day, WHO mencanangkan tema count down 2020 (mengupayakan agar penduduk dunia dapat terhindar dari masalah kebutaan dan memperolah penglihatan yang optimal).

Upaya pencegahan myopia dapat diawali dengan mengidentifikasi faktor risiko terjadinya miopia. Salah satu faktor ekstrinsik yang berpengaruh dalam perkembangan miopia adalah aktivitas melihat dekat atau nearwork dan kurangnya aktifitas di luar ruang. Adanya kemajuan teknologi dan telekomunikasi, seperti televisi, komputer, video game, dan lain-lain, secara langsung maupun tidak langsung meningkatkan aktivitas melihat dekat. Peneliti dari Chinese University of Hong Kong mengamati anak yang banyak menghabiskan waktunya pada aktivitasaktivitas jarak dekat (nearwork activity) seperti belajar, membaca, menggunakan 
komputer, bermain video game, dan menonton televisi. Tingginya akses terhadap anak terhadap media visual ini apabila tidak diimbangi dengan pengawasan ketat terhadap perilaku berisiko seperti jarak melihat yang terlalu dekat saat membaca atau menggunakan media visual serta istirahat yang kurang dapat meningkatkan terjadinya miopia pada anak sekolah (Huang, Chang, \& $\mathrm{Wu}, 2015)$. Faktor lainnya yang diduga mendukung perkembangan miopia adalah keturunan (genetik). Orang tua secara genetik dapat menurunkan sifat kelainan refraksi baik secara autosomal dominan maupun autosomal resesif. Prevalensi miopia pada anak yang kedua orang tuanya miopia adalah $32,9 \%$, sedangkan pada anak dengan hanya salah satu orang tuanya yang mengalami miopia adalah sekitar 18,2\%, dan kurang dari $8,3 \%$ pada anak dengan orang tua tanpa miopia (Komariah \& Nanda, 2014).

Data WHO (2008) menunjukkan $10 \%$ dari 66 juta anak usia sekolah menderita kelainan refraksi yaitu miopia. Penelitian juga menunjukkan hubungan yang kuat antara peningkatan skor kecerdasan dan risiko terjadinya miopia pada anak sekolah (Williams, Miller, Gazzard, \& Saw, 2008). SMP Negeri 2 Tanjungkarang merupakan salah satu sekolah menengah pertama negeri yang ada di provinsi Lampung dengan akreditasi A dan merupakan sekolah favorit di provinsi Lampung, oleh karena siswa yang diterima di sekolah ini merupakan siswa yang memiliki prestasi yang baik secara akademik dan berbakat. Hasil presurvey pada siswa SMPN 2 Tanjungkarang didapatkan sebagian siswa banyak melakukan aktifitas membaca Hasil wawancara dengan petugas UKS sekolah didapat informasi terdapat lebih dari 20 siswa dari 305 siswa yang menderita miopia $(6,5 \%)$. Berdasarkan uraian diatas peneliti tertarik untuk melakukan penelitian tentang faktor risiko yang berhubungan dengan kejadian miopia pada anak sekolah.

\section{METODE}

Jenis penelitian kuantitatif dengan desain case control. Populasi adalah semua siswa kelas 8 pada salah satu SMP di Bandar
Lampung. Jumlah sampel sebanyak 44 responden, terdiri dari 22 siswa miopia sebagai kelompok kasus dan 22 siswa tidak miopia sebagai kelompok kontrol. Pemilihan respon menggunakan teknik purposive sampling, berdasarkan kriteria inklusi.

Pengumpulan data menggunakan lembar instrument yang diberikan pada kedua kelompok. Analisa data (analisa univariat) untuk melihat distribusi frekuensi faktor risiko jenis kelamin, keturunan, aktifitas jarak dekat dan aktifitas luar ruang. Analisis bivariat untuk melihat hubungan antara faktor risiko jenis kelamin, keturunan, aktifitas jarak dekat dan aktifitas luar ruangan dengan kejadian myopia pada siswa.

\section{HASIL}

\section{Analisis Univariat}

Responden pada penelitian ini sebagian besar berjenis kelamin perempuan $(54,5 \%)$ dan sebagian besar tidak memiliki faktor keturunan myopia dari orang tuanya $(72,7 \%)$.

Tabel 1: Distribusi Frekuensi Faktor Risiko Aktifitas Jarak Dekat dan Faktor Risiko Aktifitas Luar Ruang

\begin{tabular}{lcccc}
\hline $\begin{array}{l}\text { Faktor } \\
\text { Risiko }\end{array}$ & Mean Median & SD & Min-Maks \\
\hline $\begin{array}{l}\text { Aktifitas } \\
\text { Jarak Dekat }\end{array}$ & 5,50 & 4,75 & 2,808 & $1-18$ \\
\hline $\begin{array}{l}\text { Aktifitas } \\
\text { Luar Ruang }\end{array}$ & 1,84 & 1,00 & 1,649 & $0-8$ \\
\hline
\end{tabular}

Tabel di atas menjelaskan rata-rata aktifiras jarak dekat yang dilakukan responden adalah 5,5 jam, dengan nilai median 4,75 dan standar deviasi 2,808. Lama waktu aktifitas jarak dekat minimal 1 jam dan maksimal 18 jam. Rata-rata responden melakukan aktifitas luar ruang 1,84 jam, median 1,00 jam dengan standar deviasi 1,649. Lama waktu aktifitas luar ruang minimal 0 jam dan maksimal 8 jam. 


\section{Analisis Bivariat}

Tabel 2: Distribusi Responden Menurut Kejadian Miopia Dan Faktor Risiko Jenis Kelamin

\begin{tabular}{lcccccc}
\hline \multirow{2}{*}{ Kelompok } & \multicolumn{4}{c}{ Jenis Kelamin } & \multirow{2}{*}{ Total } \\
\cline { 2 - 6 } & \multicolumn{2}{c}{ Laki-Laki Perempuan } & \\
\cline { 2 - 6 } & $\mathrm{f}$ & $\%$ & $\mathrm{f}$ & $\%$ & $\mathrm{f}$ & $\%$ \\
\hline Miopia & 10 & 45,5 & 12 & 54,5 & 22 & 100 \\
\hline Tidak Miopia & 10 & 45,5 & 12 & 54,5 & 22 & 100 \\
\hline Jumlah & 20 & 45,5 & 32 & 54,5 & 44 & 100 \\
\hline$p$ value & 1,000 & & & & \\
\hline
\end{tabular}

OR $(95 \%$ CI $) 1,000(0,305-3,277)$

Hasil analisis hubungan antara miopia dengan faktor risiko jenis kelamin pada anak sekolah, diperoleh sebanyak 12 siswa $(54,5 \%)$ yang miopia adalah perempuan, sedangkan sebanyak 10 siswa $(45,5 \%)$ lakilaki. Hasil uji statistik diperoleh nilai $\mathrm{p}=$ 1,000, maka dapat disimpulkan tidak ada hubungan yang signifikan antara jenis kelamin dengan kejadian miopia pada anak sekolah. Hasil penelitian didapat nilai $\mathrm{OR}=$ 1,000 yang artinya bahwa siswa perempuan memiliki peluang (berisiko) sebanyak 1,000 kali mengalami miopia dibandingkan dengan siswa laki-laki.

Tabel 3: Distribusi Responden Menurut Kejadian Miopia dan Faktor Risiko Keturunan

\begin{tabular}{lcccccc}
\hline \multirow{2}{*}{ Kelompok } & \multicolumn{3}{c}{ Faktor Keturunan } & \multirow{2}{*}{ Ada } & \multicolumn{3}{c}{ Tidak ada } & \multicolumn{1}{c}{ Total } \\
\cline { 2 - 6 } & $\mathrm{f}$ & $\%$ & $\mathrm{f}$ & $\%$ & $\mathrm{f}$ & $\%$ \\
\hline Miopia & 10 & 45,5 & 12 & 54,5 & 22 & 100 \\
\hline Tidak Miopia & 2 & 9,1 & 20 & 90,9 & 22 & 100 \\
\hline Jumlah & 12 & 27,3 & 32 & 72,7 & 44 & 100 \\
\hline$p$ value & 0,018 & & & & \\
\hline OR $(95 \% \mathrm{CI})$ & 8,333 & $(1,556-44,642)$ & \\
\hline
\end{tabular}

Hasil analisis hubungan antara miopia dengan faktor risiko keturunan pada anak sekolah, diperoleh sebanyak 10 siswa $(45,5 \%)$ yang miopia memiliki riwayat faktor keturunan, sedangkan sebanyak 12 siswa
$(54,5 \%)$ yang miopia tidak memiliki faktor keturunan. Hasil uji statistik diperoleh nilai $\mathrm{p}$ $=0,018$, maka dapat disimpulkan ada hubungan yang signifikan antara faktor keturunan dengan kejadian miopia pada anak sekolah. Hasil penelitian didapat nilai OR = 8,333 yang artinya bahwa siswa yang memiliki faktor keturunan miopia dari orang tuanya memiliki peluang sebanyak 8,333 kali mengalami miopia dibandingkan dengan siswa yang orang tuanya tidak miopia

Tabel 4: Distribusi Responden Menurut Kejadian Miopia dan Faktor Risiko Aktifitas Jarak Dekat

\begin{tabular}{lcccccc}
\hline & \multicolumn{3}{c}{ Faktor Aktifitas } \\
Kelompok & \multicolumn{3}{c}{ Jarak Dekat } & \multirow{2}{*}{ Total } \\
\cline { 2 - 5 } & $\geq 5$ jam & $<5$ jam & & \\
\cline { 2 - 6 } & $\mathrm{f}$ & $\%$ & $\mathrm{f}$ & $\%$ & $\mathrm{f}$ & $\%$ \\
\hline Miopia & 17 & 77,3 & 5 & 22,7 & 22 & 100 \\
\hline Tidak Miopia & 5 & 22,7 & 17 & 77,3 & 22 & 100 \\
\hline Jumlah & 22 & 50,0 & 22 & 50,0 & 44 & 100 \\
\hline$p$ value & 0,001 & & & & \\
\hline OR $(95 \%$ CI $)$ & 11,560 & $(2,822-47,356$ & \\
\hline
\end{tabular}

Hasil analisis hubungan antara miopia dengan faktor risiko aktifitas jarak dekat pada anak sekolah, diperoleh sebanyak 17 siswa $(77,3 \%)$ yang miopia memiliki aktifitas jarak dekat $\geq 5$ jam, sedangkan sebanyak 5 siswa $(22,7 \%)$ yang miopia memiliki aktifitas jarak dekat $<5$ jam. Hasil uji statistik diperoleh nilai $\mathrm{p}=0,001$, maka dapat disimpulkan ada hubungan yang signifikan antara faktor aktifitas jarak dekat dengan kejadian miopia pada anak sekolah. Hasil penelitian didapat nilai OR 11,560 yang artinya bahwa siswa yang memiliki aktifitas jarak dekat $\geq 5$ jam memiliki peluang sebanyak 11,560 kali mengalami miopia dibandingkan dengan siswa yang aktifitas jarak dekatnya kurang dari 5 jam. 


$\begin{array}{llr}\text { Tabel 5: Distribusi } & \text { Responden } & \text { Menurut } \\ \text { Kejadian Miopia dan } & \text { Faktor } \\ \text { Aktifitas Luar Ruang } & & \\ \end{array}$

\begin{tabular}{lcccccc}
\hline \multirow{2}{*}{ Kelompok } & \multicolumn{3}{c}{$\begin{array}{c}\text { Laktor Aktifitas } \\
\text { Luar Ruangan }\end{array}$} & \multirow{2}{*}{ Total } \\
\cline { 2 - 5 } & $\leq 3$ jam & $>3$ & jam & & \\
\cline { 2 - 6 } & $\mathrm{f}$ & $\%$ & $\mathrm{f}$ & $\%$ & $\mathrm{f}$ & $\%$ \\
\hline Miopia & 17 & 77,3 & 5 & 22,7 & 22 & 100 \\
\hline Tidak Miopia & 22 & 100 & 0 & 0 & 22 & 100 \\
\hline Jumlah & 39 & 88,6 & 5 & 11,4 & 44 & 100 \\
\hline$p$ value & 0,048 & & & & \\
\hline OR $(95 \%$ CI $)$ & $0,773(0,616-0,969)$ & & \\
\hline
\end{tabular}

Hasil analisis hubungan antara miopia dengan faktor risiko aktifitas luar ruang pada anak sekolah, diperoleh sebanyak 17 siswa $(77,3 \%)$ yang miopia memiliki aktifitas luar ruang $\leq 3$ jam, sedangkan sebanyak 5 siswa $(22,7 \%)$ yang miopia memiliki aktifitas jarak dekat $>3$ jam. Hasil uji statistik diperoleh nilai $\mathrm{p}=0,048$, maka dapat disimpulkan ada hubungan yang signifikan antara faktor aktifitas luar ruang dengan kejadian miopia pada anak sekolah. Hasil penelitian didapat nilai OR 0,773 (kurang dari 1) yang artinya bahwa siswa yang memiliki aktifitas luar ruang memiliki resiko lebih rendah mengalami miopia.

\section{PEMBAHASAN}

\section{Hubungan Faktor Jenis Kelamoi dengan Kejadian Miopia pada Anak Sekolah}

Miopia adalah keadaan dimana mata mempunyai kekuatan pembiasan sinar yang berlebihan sehingga sinar sejajar yang datang dibiaskan didepan retina. Penderita miopia akan melihat lebih jelas bila jaraknya dekat atau terlalu dekat, sedangkan bila melihat jauh kabur (Ilyas, 2002). Menurut Youngson (1995), myopia umumnya berkembang bersamaan dengan perkembangan tubuh (masa pubertas) dan berhenti di usia 25 tahun. Puncak myopia pada usia remaja dan banyak terjadi pada anak perempuan dibanding laki-laki dengan perbandingan 1,4:1. Namun belum ditemukan penelitian lebih lanjut tentang fenomena ini.
Responden yang ada dalam penelitian ini lebih banyak siswa perempuan dibandingkan laki-laki, yaitu 24 orang $(54,5 \%)$ sedangkan siswa laki-laki 20 orang $(45,5 \%)$, dan mayoritas yang menderita miopia adalah siswa perempuan.

Hasil penelitian menyimpulkan tidak ada hubungan antara jenis kelamin dengan kejadian miopia pada anak sekolah. Meskipun secara teori terdapat hubungan antara jenis kelamin dengan kejadian miopia, dan dari hasil penelitian didapatkan hasil yang sesuai, namun perlu penelitian lebih lanjut pada populasi yang lebih luas dengan karakteritik usia yang lebih heterogen, dikarenakan pada penelitian ini usia siswa cenderung homogen.

\section{Hubungan Faktor Keturunan dengan Kejadian Miopia pada Anak Sekolah}

Hasil penelitian didapatkan ada hubungan antara faktor keturunan dengan kejadian miopia pada anak sekolah Hasil penelitian ini diperkuat dengan hasil penelitian Nurjannah (2018) bahwa riwayat genetik merupakan faktor risiko utama penyebab miopia $(\mathrm{OR}=2.23$; 95\% CI; 1,234.02). Faktor genetik dapat menurunkan sifat kelainan refraksi ke keturunannya, baik secara autosomal dominan maupun autosomal resesif.

Penelitian Rose, dkk (2008) membandingkan prevalensi dan faktor risiko miopia pada anak-anak etnis Cina di Sydney dan Singapura dengan kriteria inklusi kedua orang tua memiliki etnis Cina. Prevalensi miopia pada anak dari etnis Cina lebih tinggi di Singapura $(29,1 \%)$ daripada di Sydney (Rose et al., 2008). Beberapa kromosom yang terkait dengan miopia antara lain 22q12,14q, 4q22-28, 8q22.2, 10q22, $11 \mathrm{q} 23,13 \mathrm{q} 22,14 \mathrm{q} 23$, dan 17qter. Gen PAX6 yang ada pada kromosom 11q23 menunjukkan adanya keterkaitan dengan 5 SNP (Young, 2009), dan gen PAX6 memiliki keterkaitan dengan miopia yang tinggi dan ekstrim (Tang et al., 2014).

Pada penelitian ini terdapat 9 siswa $(20,4 \%)$ yang salah satu orangtua nya memiliki riwayat myopia yaitu ayah saja atau ibu saja. Siswa yang kedua orangtua nya 
(ayah dan ibu) memiliki riwayat miopia ada 2 orang $(4,5 \%)$. Meskipun demikian ada juga siswa yang salah satu orangtuanya memiliki riwayat miopia namun siswa tersebut tidak menderita miopia. Hasil penelitian didapat nilai OR 8,333 yang artinya bahwa anak yang memiliki faktor keturunan dari orang tuanya berisiko 8,333 kali mengalami miopia dibandingkan dengan yang tidak.

Menurut Komariah \& Nanda (2014), anak dengan orang tua yang mengalami kelainan refraksi cenderung juga mengalami kelainan refraksi. Prevalensi miopia pada anak yang kedua orang tuanya miopia adalah $32,9 \%$, sedangkan pada anak dengan hanya salah satu orang tuanya yang mengalami miopia adalah sekitar 18,2\%, dan kurang dari $8,3 \%$ pada anak dengan orang tua tanpa miopia.

Berdasarkan uraian diatas, maka responden yang memiliki riwayat faktor keturunan memiliki risiko yang lebih besar untuk mengalami miopia dibandingkan dengan responden yang tidak memiliki faktor keturunan dari orang tuanya, sehingga untuk siswa yang memiliki riwayat keurunan agar mengurangi aktifitas-aktifitas dan kebiasaan buruk untuk mencegah agar miopia tidak bertambah.

\section{Hubungan Faktor Aktifitas Jarak Dekat dengan Kejadian Miopia Anak Sekolah}

Hasil penelitian ini sesuai dengan penelitian Rahimi, et.al (2015), yang menunjukkan bahwa kelompok kasus (miopia) cenderung lebih banyak menghabiskan waktu beraktivitas dekat lebih dari 3 jam dalam sehari.

Menurut Kristianti (2008), aktivitas melihat jarak dekat yang terlalu berlebihan akan menyebabkan mata menjadi mudah lelah. Anak-anak yang banyak menghabiskan waktunya untuk melakukan aktivitas aktivitas jarak dekat seperti membaca, menggunakan komputer, bermain video games, menonton televisi akan lebih berisiko untuk terjadi myopia dikarenakan adanya efek fisik langsung akibat akomodasi yang terjadi secara terus menerus sehingga menyebabkan tonus otot siliaris pada bola mata menjadi tinggi dan lensa menjadi cembung. Jarak yang semakin dekat akan menyebabkan semakin kuatnya akomodasi mata (Kistianti, 2008). Jarak terlalu dekat membaca buku, menonton televisi, bermain games, main komputer, main handphone ponsel, dan sebagainya. Terlalu lama beraktifitas pada jarak pandang yang sama seperti bekerja didepan komputer, didepan layar monitor, didepan mesin, didepan berkas, dan lain-lain menyebabkan mata terus berkontraksi sehingga otot mata jadi tidak normal. Serta kebiasaan buruk yang dapat mengganggu kesehatan mata seperti membaca sambil tidur-tiduran, membaca ditempat yang gelap, membaca dibawah sinar matahari langsung yang silau, menatap sumber cahaya terang langsung, dan lain sebagainya harus dihindari.

Menurut Huang et.al (2015) semakin banyak dan lama waktu yang dihabiskan untuk aktivitas jarak dekat, akan semakin besar risiko terjadinya miopia. Lamanya aktivitas melihat jarak dekat akan menstimulasi perubahan perubahan biokimia dan struktural pada sklera dan koroid yang menyebabkan elongasi aksial (Ramamurthy, Lin Chua, \& Saw, 2015).

Hasil penelitian didapatkan jenis aktifitas jarak dekat yang dilakukan oleh siswa yang menggunakan waktu lebih dari 5 jam adalah smartphone, yaitu dilakukan oleh 7 orang siswa $(15,9 \%)$, dan ke-7 siswa tersebut semuanya menderita miopia. Jenis katifitas jarak dekat lain yang sering dilakukan oleh siswa yaitu membaca, dan menonton televisi. Dari hasil penelitian diperoleh nilai $\mathrm{OR}=11,560$ yang berarti bahwa responden yang mempunyai aktifitas jarak dekat lebih dari 5 jam dalam sehari memiliki risiko sebanyak 11,560 kali dibandingkan dengan responden yang aktifitas jarak dekatnya kurang dari 5 jam. Untuk mencegah berkembangnya miopia pada responden sebaiknya responden mengurangi jumlah jam aktifitas jarak dekat yang dilakukannya atau dengan cara setiap 20 menit istirahat selama 20 menit dan memandang sejauh 20 meter.

Berikut beberapa upaya untuk mencegah terjadinya miopia yang disebabkan aktifitas jarak dekat yang banyak dilakukan oleh siswa yaitu menonton televisi jangan terlalu dekat, jarak aman untuk menonton 
televisi 2 meter untuk TV ukuran 14 inchi, Nonton layar bioskop sebaiknya ambil kursi yang paling belakang. Bekerja dan bermain komputer jangan terlalu lama, biasakan memberi waktu dalam beraktivitas didepan layar komputer. Misalnya setiap 15 atau 30 menit sekali beristirahat melihat yang jauhjauh selama 5 sampai 10 menit agar mata tidak selalu dalam keadaan tegang karena melihat layar dengan jarak yang sangat dekat. Bermain video game jangan terlalu dekat. Jarak yang aman membaca buku adalah 30 $\mathrm{cm}$. Bila terlalu dekat dapat membuat mata tegang dan mengakibatkan rabun jauh dalam jangka panjang. Membaca buku juga tidak boleh sambil tiduran. Penerangan juga harus cukup misalnya dengan lampu neon yang terang. Dengan demikian kesehatan mata akan tetap terjaga.

\section{Hubungan Faktor Aktifitas di Luar Ruang dengan Kejadian Miopia Anak Sekolah}

Penelitian Lisa A. Jones et al. (2007) menyatakan bahwa aktivitas di luar ruangan yang rendah akan meningkatkan kejadian miopia pada anak yang memiliki kedua orang tua miopia. Penelitian di Australia membandingkan gaya hidup anak dari etnis Cina yang tinggal di Sidney, dengan yang tinggal di Singapura didapatkan sebanyak $29 \%$ anak-anak di Singapura mengalami miopia, sedangkan di Sidney hanya 3,3\% yang miopia. Padahal, anak-anak di Sidney membaca lebih banyak buku tiap minggu dan melakukan aktifitas dalam jarak dekat lebih lama daripada anak di Singapura, tetapi mereka juga menghabiskan waktu di luar rumah lebih lama $(13,75$ jam per minggu) dibandingkan dengan anak-anak di Singapura (3,05 jam) (Sahat, 2006).

Hasil penelitian diperoleh sebanyak $77,3 \%$ siswa dengan miopia melakukan aktifitas di luar ruang kurang dari 3 jam. Jenis aktifitas di luar ruang yang dilakukan yaitu olah raga berenang, futsal, bulu tangkis, basket, pencak silat dan sebagainya dengan lama waktu rata-rata 1,84 jam. Dari hasil penelitian diperoleh nilai $\mathrm{OR}=0,773$ yang berarti bahwa responden yang memiliki aktifitas di luar ruangan selama kurang dari 3 jam memiliki risiko sebanyak 0,773 untuk mengalami miopia, sehingga responden disarankan untuk dapat meningkatkan jumlah jam aktifitas di luar ruang.

Aktivitas di luar ruangan merupakan suatu faktor protektif yang dapat mencegah terjadinya miopia. Terdapat mekanisme yang mendukung aktivitas di luar ruangan sebagai faktor protektif yaitu meningkatnya depth of focus dan kejernihan retina yang menyebabkan konstriksi pupil karena intensitas cahaya yang tinggi dan berkurangnya permintaan untuk melihat jarak dekat saat berada di luar ruangan. Semakin tinggi intensitas cahaya, tingkat perlindungan terhadap miopia juga semakin meningkat (Ramamurthy et al., 2015). Paparan cahaya yang terang akan menstimulasi pelepasan dopamin yang dapat menghambat elongasi bola mata (French, Ashaby, Morgan, \& Rose, 2013). Teori lainnya yaitu bahwa paparan radiasi ultraviolet $B$ (UVB) dapat menstimulasi pelepasan vitamin D. Vitamin $\mathrm{D}$ berperan dalam pembentukan kolagen yang merupakan komponen utama sklera (Ramamurthy et al., 2015).

\section{KESIMPULAN}

Hasil penelitian ini menyimpulkan bahw tidak ada hubungan antara faktor risiko jenis kelamin dengan kejadian miopia pada anak sekolah. Namun sebaliknya ada hubungan faktor risiko keturunan, faktor risiko aktifitas jarak dekat dan faktor resiko aktifitas di luar ruangan dengan kejadian miopia pada anak sekolah.

Berdasarkan simpulan tersebut penulis menyarankan untuk mencegah berkembangnya miopia pada siswa sekolah sebaiknya dilakukan dengan cara mengurangi jumlah jam aktifitas jarak dekat yang dilakukannya atau dengan cara setiap 20 menit istirahat selama 20 menit dan memandang sejauh 20 meter. Cara lain adalah dengan meningkatkan jumlah jam aktifitas di luar ruang selama lebih dari 3 jam seperti olah raga dan kegiatan lain yang dilakukan di luar ruangan.

Selanjutnya bagi siswa yang memiliki faktor resiko keturunan agar mengurangi aktifitas dan kegiatan yang dapat mencegah 
bertambahnya miopi seperti membaca, bermain smartphone selama lebih dari 5 jam dalam sehari.

\section{DAFTAR PUSTAKA}

French, A. N., Ashaby, R. S., Morgan, I.G. \& Rose, K. A. (2013). Time Outdoors and The Prevention of Myopia. Experimental Eye Research Journal, 111.

Huang H.M, Chang, D.S.T. \& Wu, P.C. (2015). The Association between near work activities and myopia in children - A Systematic Review and Meta-Analysis. Plos One, 1-15

Ilyas, S. (2002). Ilmu Penyakit Mata. Edisi Ke-3. Jakarta: Balai Penerbit FKUI..

Kistianti F. (2008). Faktor Risiko Yang Berhubungan dengan Terjadinya Cacat Mata Miopia pada Mahasiswa. Jurnal Ilmu Keperawatan UGM, 78-84.

Komariah C. \& Nanda, W.A. (2014). Hubungan Status Refraksi, dengan Kebiasaan Membaca, Aktivitas di Depan Komputer dan Status Refraksi Orang Tua pada Anak Usia Sekolah Dasar. Jurnal Kedokteran Brawijaya, 137-140.

Nurjannah. 2018. Skrinning Myopia pada Siswa Sekolah Dasar di Kabupaten Temanggung. Jurnal Ilmu Kesehatan Masyarakat, 134-140.
Ramamurthy, D., Chua, S.Y.L. \& Saw, S.M. (2015). A Review of Environmental Risk Factors for Myopia During Early Life, Childhood and Adolescence. Clinical and Experimental Optometry, 497-506.

Rahimi, B.M., Yanwirasti \& Sayuti, K. (2015). Faktor-Faktor yang Mempengaruhi Insiden Myopia pada Siswa SMA di Kota Padang. Jurnal Kesehatan Andalas, 901-907.

Rose K.A, et al. (2008). Myopia, Lifestyle, and Schooling in Students of Chinese Ethnicity in Singapore And Sydney. Archives of Ophthalmology, 527-530.

Tang, S.M., Rong, S.S., Young, A.L., Tam, P.O.S., Pang, C.P., \& Chen, L.J. (2014). PAX6 Gene Associated with High Myopia. Optometry and Vision Science, 419-29.

WHO. World Health Organization (WHO). 2011. Visual impairment and blindness.http://www.who.int/mediacen trelfactsheet.

Williams, C. Miller, L.L. Gazzard, G. \& Saw, S.M. (2008). A Comparison of Measures of Reading and Intelligence as Risk Factors for The Development of Myopia in A UK Cohort of Children. British Journal of Ophthalmology, 1117-1121.

Yu L, Li, Z.K. Gao, J.R. Liu, J.R \& Xu, C.T. (2011). Epidemiology, Genetics And Treatments For Myopia. International Journal of Ophthalmology, 658-69.

Youngson, R. (1995). Penyakit Mata. Jakarta: ARLAN. 